\title{
К ВОПРОСУ ТЕКУЩИХ ПРОБЛЕМ ЭКСПЛУАТАЦИИ ПХГ И МЕТОДЫ ИХ РЕШЕНИЯ
}

\author{
cm.npen. Д. Г. Азизова, \\ ст.преп. Н. М. Авлаярова, \\ ст.преп. Б. Ю. Номозов, \\ асс. А. А. Тукаева, \\ Узбекистан, Каршинский Инженерно-Экономический Институт
}

DOI: https://doi.org/10.31435/rsglobal_wos/31012019/6309

\section{ARTICLE INFO \\ Received: 28 November 2018 \\ Accepted: 21 January 2019 \\ Published: 31 January 2019 \\ KEYWORDS \\ Underground gas storages, cyclic operation, seasonal unevenness, destruction of a cement stone, bottomhole zone gas-manifestations, day surface, buffer and active gas, gas overflows.}

\begin{abstract}
In article questions about current problems of operation of underground storage of gas are considered, graphic dynamics of creation of cyclic operation of UGS the showing interdependence of volume of the pumped gas and the specified reservoir pressure allowing to track easily volumes of active and buffer gas is given. Some recommendations and methods for increase in efficiency of wells, decrease in their water content and sand production are also provided.
\end{abstract}

Citation: Д. Г. Азизова, Н.М.Авлаярова, Б.Ю.Номозов, А. А. Тукаева. (2019) К Voprosu Tekushchih Problem Ehkspluatacii PHG i Metody ih Resheniya. International Academy Journal Web of Scholar. 1(31), Vol.1. doi: 10.31435/rsglobal_wos/31012019/6309

Copyright: (C) 2019 Д. Г. Азизова, Н. М. Авлаярова, Б. Ю. Номозов, А. А. Тукаева. This is an open-access article distributed under the terms of the Creative Commons Attribution License (CC BY). The use, distribution or reproduction in other forums is permitted, provided the original author(s) or licensor are credited and that the original publication in this journal is cited, in accordance with accepted academic practice. No use, distribution or reproduction is permitted which does not comply with these terms.

Введение. Основным предназначением подземных хранилищ газа (ПХГ) является регулирование сезонной неравномерности потребления газа народным хозяйством. То есть объекты ПХГ являются неотъемлемой частью системы газоснабжения страны. Как и любой технологический объект ПХГ имеет свои особенности, поскольку его эксплуатация носит циклический характер, в процессе которой поочередно осуществляются процессы закачки газа и отбора его из пласта. В этой связи чаще возникают проблемы эксплуатации скважин, такие как разрушение цементного камня за колоннами из-за износа и переменных нагрузок на ствол скважины, следствием которых, в свою очередь, могут стать перетоки газа в другие горизонты или даже прискважинные газопроявления на дневной поверхности. Перечисленные выше проблемы имеют место также на ПХГ нашей Республики.

Основная часть. Создание подземного хранения газа ПХГ на базе выработанной газовой залежи в IX горизонте месторождения Луч началось в 1988 г, при эксплуатационном фонде из 133 скважин и пластовом давлении 7,15 кгс/см².

За истекший период (1988-2017 гг.) реализовано 29 полных циклов эксплуатации рассматриваемого ПХГ и сезон закачки 2017 г. закончился суммарной закачкой газа в объёме

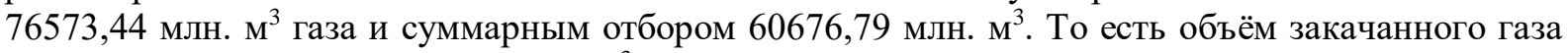
выше отобранного на 15896,65 млн. м³.

В текущем эксплуатационном фонде 289 скважин, из них 273 эксплуатационнонагнетательные и 16 скважин со вскрытием нижних горизонтов (X, XI+XIa, XII) месторождения Луч. 
Графически динамика создания и циклической эксплуатации ПХГ, с 1988 по 2017 гг, представлена на рисунке 1, показывающая взаимозависимость объёма закачанного газа и приведённого пластового давления в ПХГ, что позволяет легко проследить объёмы активного (Vmax-Vmin) и буферного газа (Vmin). [4]

Как видно из рисунка 1, с 1988 по 2000 гг. объём газа в ПХГ постоянно увеличивается, а максимальное давление достигается в конце закачки 1999 г. - 18,98 кгс/см². Характерной особенностью дальнейшего периода эксплуатации ПХГ (1999-2007 гг.) является наблюдаемое снижение пластового давления при практически неизменных балансовых объёмах закачанного в ПХГ газа. Так, при таком же закачанном объёме газа $\left(19,6\right.$ млрд. м $\left.^{3}\right)$, пластовое давление в конце закачки в 2007 г. составило 17,2 кгс/см² против 18,98 - в 1999 г.

В это же время в нижележащем X горизонте наблюдается повышение давления с 6,0 до

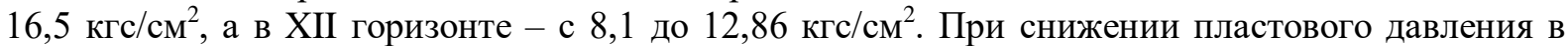
ПХГ до 10,4 кгс/см² в конце отбора газа в апреле 2011 г. в X и XII горизонтах также наблюдалось снижение пластового давления. На рисунке 2 представлена динамика пластовых давлений в продуктивных горизонтах месторождения Луч. Наблюдаемая на рисунке 2 практическая синхронность динамики давлений, указывает на гидродинамическую связь между IX (ПХГ) и нижележащими X, XII горизонтами, обусловливающую перетоки газа в процессе эксплуатации ПХГ.

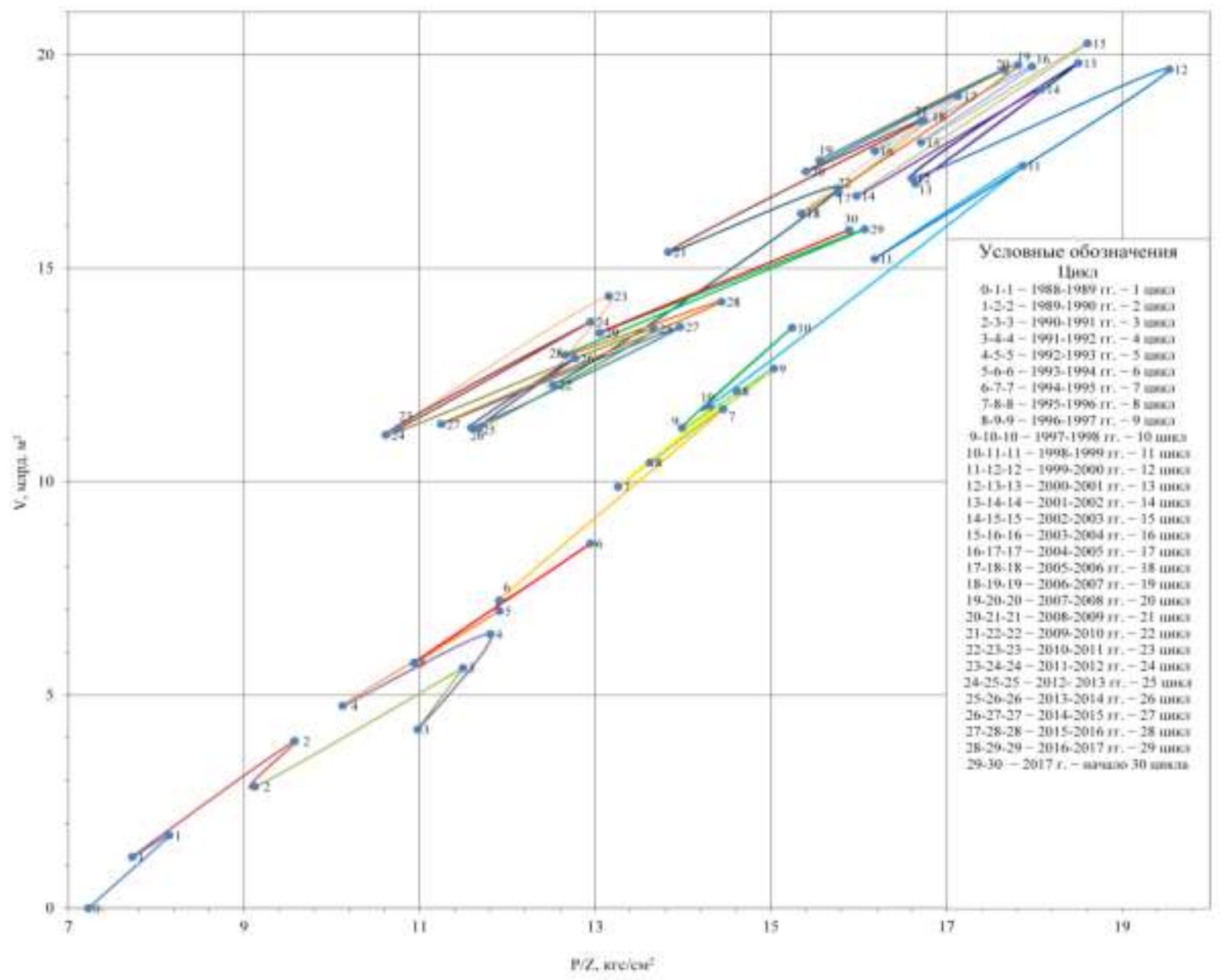

Рис.1. Динамика параметров (объём, давление) циклической эксплуатации ПХГ Луч 


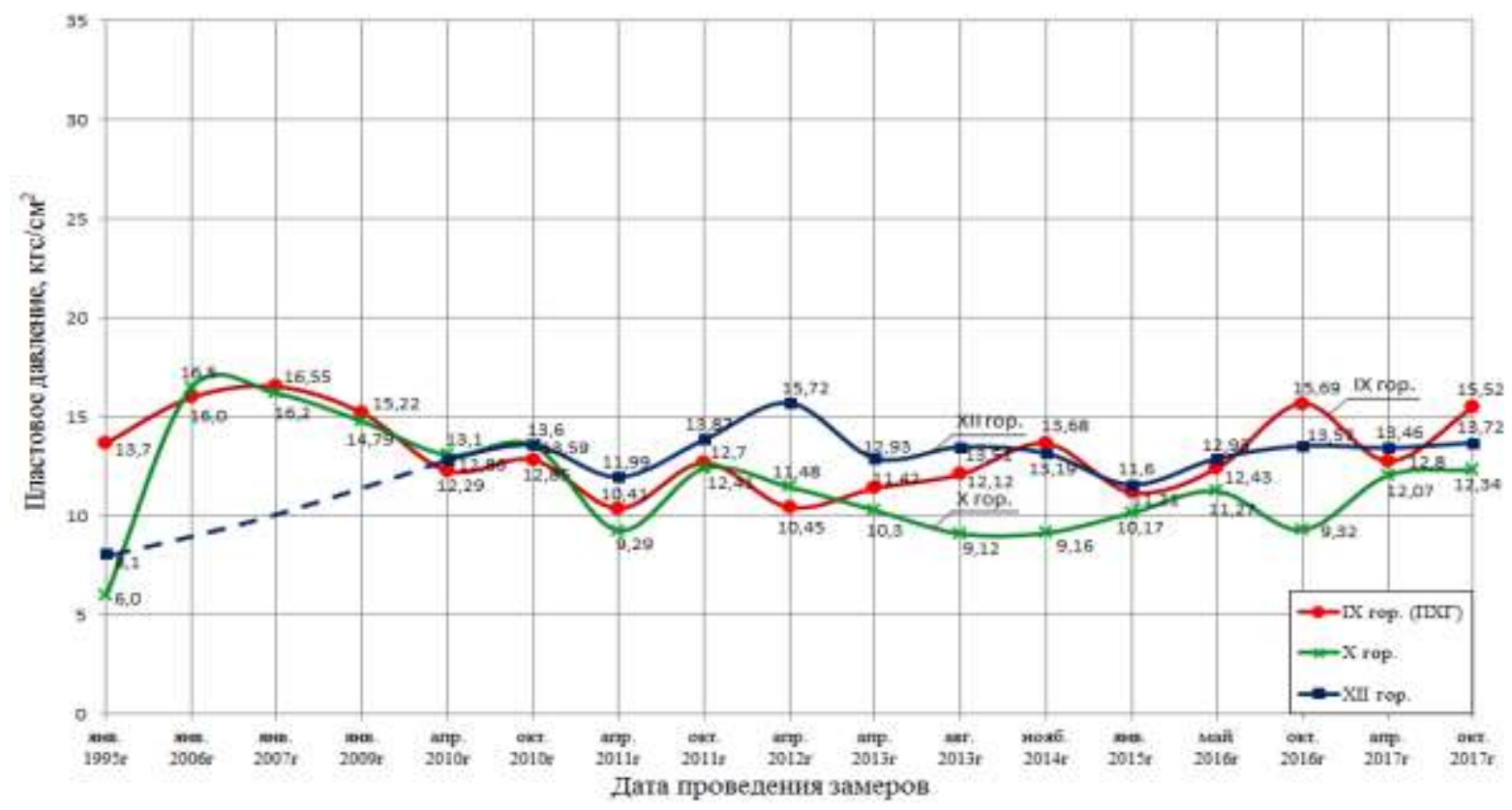

Рис.2. Динамика пластовых давлений в продуктивных горизонтах месторождения Луч

Текущее пластовое давление (на конец закачки 2017 г.) составляет

- IX горизонт - 15,52 кгс/ $\mathrm{cm}^{2}$;

- Х горизонт - 12,34 кгс/см² (замеры в 6 скважинах);

- XII горизонт - 13,72 кгс/см² (замеры в 8 скважинах).

Сложившийся баланс системы позволяет эксплуатировать рассматриваемое ПХГ с активным объёмом газа 3,0 млрд. м³.

В случае расширения ПХГ необходимо провести техническое обследование его эксплуатационного фонда скважин с выявлением возможных перетоков и качества заколонного цемента и цементных мостов, поскольку основной фонд скважин эксплуатируется более 50 лет и имеет высокий физический износ, а из 273 скважин - 198 скважин переведены после эксплуатации на нижезалегающих горизонтов с вытекающими отсюда последствиями. [2]

Анализ ГИС за последние 6 лет эксплуатации ПХГ (2012-2017 гг.) с охватом практически всего эксплуатационного фонда скважин, из которого были выбраны 182 скважины, в которых замером охвачены все коллектора, в том числе скважины, в которых отмечается уровень ГВК и нижние коллектора обводнены. [1]

По результатам данного анализа были построены карты газонасыщенности, газонасыщенной мощности и произведения этих величин, по которым отмечается сокращение газонасыщенной мощности практически по всему фонду эксплуатационных скважин в сравнении с их начальными значениями при создании ПХГ. В среднем, по ПХГ, газонасыщенная мощность сократилась с 36,0 м до 25,9 м. На скважинах ГСП-3, 9 на 60\%, ГСП-1, 4 - на 50\%, ГСП-7 - на 24\% и на $10 \%$ на скважинах ГСП-5, 8.

Значения газонасыщенности, в среднем, уменьшились с 65,8\% до 59,7\%, причем снижение газонасыщенности на 7-15\% отмечается на скважинах ГСП-1, 3, 4, 9, объёмы закачки в скважины которых почти в 2 раза меньше, чем в скважины ГСП-2, 5, 7, 8, в которых газонасыщенность практически не изменилась.

По динамике газонасыщения коллекторов видно, что закачиваемый газ практически не оттесняет воду в обводненной части, а поступает в газонасыщенную часть залежи. [4]

Скважины эксплуатируются в условиях, когда давление в газовой зоне значительно ниже гидростатического в водоносной, происходит обводнение скважин контурными водами по наиболее проницаемым, легко дренируемым пропласткам. При этом, слабо дренируемые пропластки остаются газонасыщенными, но не способными отдавать газ. Призабойная зона эксплуатационных скважин быстро обводняется, вплоть до задавливания скважины, снижаются как темпы отбора газа, так и способность принимать закачиваемый газ. 
Анализ ГИС показал [1] что 55 скважин эксплуатационного фонда в процессе закачки задавлены уровнем жидкости, из чего следует, что газ эти скважины не принимают и нуждаются в проведении специальных исследований и интенсификации пласта-коллектора.

Выводы. Для повышения продуктивности скважин, снижения их обводнённости и выноса песка, рекомендуется проводить осушку пласта-коллектора с применением поверхностно-активных веществ, образующих при взаимодействии с закачиваемым газом устойчивую пену, способную оттеснить воду вглубь пласта при закачке газа, тем самым, осушая его, и препятствуя продвижению пластовой воды при отборе газа.

Кроме проблем, возникающих в процессе эксплуатации ПХГ, перед специалистами научно сопровождающими работу ПХГ ставятся задачи, требующие не только грамотного технологического решения и технического исполнения, но и, что особенно важно в условиях рыночной экономики, экономически обоснованного подхода. [3]

Одной из задач, стоящих в настоящее время является наращивание активного объема газа в ПХГ (обоснованных объемов хранения газа, которые можно отобрать из пласта в сезон холодов) не только для обеспечения жителей Республики, но также и с точки зрения реализации экспортных поставок в холодный сезон, экономический эффект от которых будет значительно выше вследствие высокой экспортной цены на газ.

\section{ЛИТЕРАТУРА}

1. Гриценко А.И., Алиев С.3. «Руководство по исследованию скважин» М.: Наука 1995 г.

2. Бузинов С.Н. Эффективность подземного хранения газа в системе газоснабжения страны: Обзорная информация. Москва 1990 г.

3. Зиновев В.В., Будзуляк Б.В., Ананенков и др. Повышение надежности и безопасности эксплуатации подземных хранилищ газа. -М.: Недра - Бизнесцентр, 2005.

4. Лысова О. Г. и др. «Оперативный анализ и авторский надзор за созданием и эксплуатацией ПХГ Луч (IX гор.) с выработкой мер по эффективной эксплуатации. Ташкент, AO «O’ZLITINEFTGAZ» 2017 г. 